D220

\title{
eラーニングによる労働安全衛生教育に関する ニーズ・課題調查
}

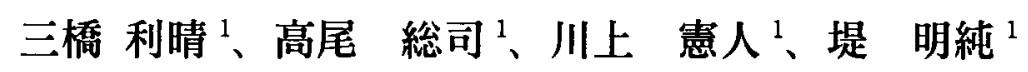

${ }^{1}$ 岡山大学大学院医歯学総合研究科・衛生学・予防医学分野

【目的】

近年、職場においてインターネットなどの情報技術を用いた学習(eラーニング)を労働安全衛生教育に活用す ることが注目されている。先進学習基盤協議会(ALIC)の調查によると、16.1\%の企業で e ラーニングが導入 されている。特に「労働安全・衛生・環境・品質」には $11.5 \% て ゙$ 導入され、今後の導入への期待は $21 \%$ とな っている。本研究では、 e ラーニングによる労働安全衛生教育に対するニーズや課題を明らかにすることを 目的としている。

[方法]

データベース会社の有する 8,000,076 件の企業データを企業群A（従業員数 50 999 人の企業）と企業群B （従業員数 1000 人以上）に分け、各々の群からランダムに 500 社を抽出し、12 月上旬に調查票を送付した。 調䍒票では、e ラーニングによる労働安全衛生教育の導入状況、関心、利点・欠点についてたずねた。最終 的に 136 社より回答が得られた（回答率 13.6\%)。このうち社の方針で回答不可能とされた 3 社を除く 133 社を有効回答とした。

[結果]

企業群Bでは多くの企業が e ラーニングによる学働安全衛生教育を導入するか、あるいは関心を持っていた。 企業群Aではこれにくらべて導入・関心をもつ企業の割合は少なかった。未導入の企業の多くからは、問題 点として e ラーニング導入にかかるコストが挙げられた。

[考察]

規模の大きな企業の多くが e-ラーニングによる労働安全衛生教育に好意的な態度を示していた。中規模以下 の企業の関心はまだ低かった。導入を阻害する要因としてeラーニング導入にかかるコストが挙げられた。 e-ラーニングを低コストで提供する方策や複数企業の共同利用などの形で 1 社あたりの負担下げることが対 策として考えられる。 